\title{
Subjective Wellbeing in the New China: \\ Religion, social capital, and social status
}

\author{
Forthcoming in British Journal of Sociology
}

Final Author text December 2015

\author{
Yunsong Chen \\ Nanjing University \\ yunsong.chen@nju.edu.cn \\ Mark Williams \\ University of Surrey \\ m.t.williams@surrey.ac.uk
}

\begin{abstract}
We present the first nationally representative evidence on the relationship between religion and subjective wellbeing for the case of China. Research on Western societies tends to find a positive association between being religious and level of wellbeing. China provides an interesting critical case as the religious population is growing rapidly and the religious and socioeconomic environments are profoundly different from Western societies, implying different mechanisms might be at work. We hypothesise to find a positive association between religion and wellbeing in China too, but argue social capital, for which strong evidence is often found in Western societies, is unlikely to be an important mechanism because religion in China is generally non-congregational. Instead, we argue that the private and subjective dimension of religion matters for wellbeing in China by helping adherents have an improved sense of social status relative to the non-religious in the context of rapid social change and growing inequality. Our results generally support these predictions.
\end{abstract}

\section{Key Words:}

China; religion; religiosity; social capital; subjective social status; subjective wellbeing

Word count:

8,967 


\section{Subjective Wellbeing in the New China: \\ Religion, social capital, and social status}

\section{Introduction}

Understanding the determinants and correlates of subjective wellbeing has become a key policy goal for many countries in recent years. An extensive academic literature on the related concepts of subjective wellbeing, happiness, and life satisfaction now exists. In this article, we investigate the role of religion, which has been highlighted as an important determinant of wellbeing in the Western literature. This article provides the first representative portrait for the case of China, the world's largest transitioning economy, where the context of religion is quite different from Western societies.

China provides an interesting case for three main reasons. First, unlike most Western societies where numbers of religious adherents are generally in decline, numbers have substantially increased in China over the last few decades (Lu 2012; Stark and Liu 2011; Yang 2006, 2011). This trend therefore may make religion a particularly salient factor for shaping future aggregate Chinese wellbeing. Second, in terms of the purported mechanisms connecting religion to higher levels of wellbeing, Western research generally finds that social capital resources derived from practicing religion explains why adherents tend to have higher levels of wellbeing (e.g., Lim and Putnam 2010). Given China's non-church religious traditions and its historical suspicions of organized belief systems, how and why religion relates to subjective wellbeing might be quite different from what is known in Western societies, where religion is generally more organized and church-based.

Third, another strand in the existing literature purports that religious beliefs can act as a psychological buffer against life's changes and uncertainties, providing an enduring sense of meaning and purpose for adherents, independent of the (rapidly changing) socioeconomic context on feelings of self-concept and wellbeing (Norris and Inglehart 2004; Inglehart 2010). Recent survey evidence suggests a trend of growing status anxiety as one of the most salient consequences of rapid social change in China (Chen and Fan 2015; Chen and Williams 2016). As social status is a strong independent predictor of wellbeing (Zhao 2012), and perhaps increasingly so, we conjecture if higher levels of wellbeing are found for adherents relative to the non-religious in China, this could in part be due to the higher sense of self religion affords to adherents, who we conjecture might be less psychologically affected by their socioeconomic conditions than the non-religious. The role of social status as a potential intervening variable in explaining any connection between religion and wellbeing is a largely untested hypotheses and one that we seek to clarify in the Chinese context.

The mechanisms linking religion to subjective wellbeing in the Chinese context have not been investigated in detail. In this article, we aim to fill this gap by answering two questions: (1) What is the relationship between religion and subjective wellbeing in contemporary China? And if a relationship exists, (2) what are the mechanisms? In what follows, we present the first nationally representative account 
on the relationship between religion and wellbeing in China. Importantly, we examine how and why religion predicts wellbeing in China, with its different religious traditions and different socioeconomic conditions compared to Western societies. We show that religion does indeed positively predict wellbeing in China, but the mechanisms we uncover are quite different to what has been shown for Western societies. In the Chinese context, we find little evidence for religious social capital explanations. Instead, we find evidence for the more private aspects of religion, in particular, improved feelings of social status, especially amongst Buddhists and Protestants. The rest of the article is organized as follows. We first review the existing studies on the relationship between religion and subjective wellbeing, describe the rise of religion in contemporary China and possible mechanisms as to how it might be connected to wellbeing, then derive some hypotheses. Next, we describe our data, variables, and analytical strategy, followed by our empirical findings and discuss implications of them for the wider sociological wellbeing literature.

\section{Religion and Subjective Wellbeing}

Subjective wellbeing conventionally refers to global feelings of wellbeing about life as perceived by individuals themselves (Campbell, Converse, and Rodgers 1976). Numerous studies have addressed how and why a long list of factors, such as income, health, age, gender, marital status, religion, status, and social capital, determine wellbeing (see reviews by Frey and Stutzer 2002 and Dolan et al. 2008). In particular for this article, numerous studies demonstrate that religion plays a substantial role in shaping subjective wellbeing in many Western societies (see e.g., Ferriss 2002; Gruber 2005; Clark and Lelkes 2006, 2009; Greeley and Hout 2006; Brooks 2008; Snoep 2008; Inglehart 2010).

Whilst the connection between religion and wellbeing is well established in Western countries, sociological research has also begun to address the underlying mechanisms connecting religion with wellbeing too. In an influential study, Lim and Putnam (2010) identify two distinct sets of mechanisms, which they label "public aspects" and "private/subjective aspects" of religion. "Public aspects" refer to the supportive social networks and frequent interaction brought about by religious congregation, resulting in higher levels of wellbeing for adherents relative to the non-religious. Using panel data for the US, they find evidence that it is the social and participatory aspects of practicing religion that increases life satisfaction, whereas "private aspects" (such as belief in god or praying privately) have no association. Similarly, Clark and Lelkes (2006) demonstrate that attending religious congregations has stronger mediating effects on the positive association between holding religious beliefs and wellbeing than praying in private across several European countries.

With regard to "private/subjective aspects", there is more variation in the concepts adopted than public aspects, which are perhaps more straightforward. Private aspects have tended to include indicators of private religious practice and religious beliefs, or focus on broader subjective concepts connected to holding religious beliefs. In a US study Greely and Hout (2006) combine several psychological and attitudinal elements of private aspects of religion such as "feeling God's love" and "feelings of 
deep inner peace and harmony" into a single dimension which they label "religious feeling" and find this fully explains the religious wellbeing gap. Other evidence demonstrates that broader psychological indicators such as meaning in life or feelings of tranquility explain the religious wellbeing gap (Hayward and Krause 2014; Steger and Frazier 2005; Ellison et al. 2009).

\section{The Rise of Religion in the New China}

China has seen a rebound in religion following the 1982 "Document 19", which guaranteed that the government would respect and protect belief in five sanctioned religions: Buddhism, Taoism, Islam, and the Catholic and Protestant denominations of Christianity (Potter 2003). In 2005, the Chinese State Administration for Religious Affairs (CSARA) publicly acknowledged that family and friends have the right to meet at home for worship without registering with the government. Although it is difficult to estimate the populations of certain non-congregational religions, such as Buddhism and Taoism, the CSARA states that there were around 100 million members of organized religions in China in the mid-2000s, of which 21 million were Muslims and 16 million are Protestants (US Department of State 2010).

However, these are likely underestimations. As Yang (2006) demonstrates, congregational leaders of Protestant and Catholic churches are often discouraged from reporting the real numbers of worshippers because of governmental regulation on congregation sizes. Survey evidence therefore generally reports higher rates. Lu (2012), using survey evidence, estimates around 10 per cent of the Chinese population belongs to an organized religion. The rate is likely much higher still if people who held some religious beliefs or belong to non-congregational religions are included. ${ }^{1}$ Irrespective of exact numbers of the size of the religious population, estimates generally agree that what is especially striking in contemporary China is the growth in religion. Stark and Liu (2011), for instance, report that the number of Christians has grown at a rate of 15 per cent per year for the past three decades, with other religions experiencing rapid growth rates. Religion, then, is fast becoming a salient feature of the new China.

Despite some representative evidence on the religion-wellbeing connection existing for a few other Asian societies also experiencing a surge in religion (Swinyard et al. 2001; Liu et al. 2012; Liu 2009), the sparse findings that do exist for China are generally based on small unrepresentative samples and generally do not attempt to distinguish between different mechanisms that connect religion to levels of wellbeing. Brown and Tierney (2009), for instance, using survey data on elderly urban Chinese residents (older than 80), find a strong but negative relationship between religious participation and wellbeing. Using data from two South-West counties devastated by the Wenchuan Earthquake in 2009, Wang et al. (2012) find that religion helped Buddhists recover from the trauma more quickly than non-Buddhists, however. Based on a sample of 880 young rural Chinese women, Wei

\footnotetext{
1 Our data shows that around 13 per cent respondents report being religious and is probably the most reliable figure given the representativeness of our data and the fact our measure captures believers as well as members of organized religions.
} 
and Liu (2013) reveal an inverse U-shaped relationship between intrinsic religiosity and depression. Whilst these studies can shed some light on the relationship between religion and wellbeing in China, they are limited to either certain demographic groups or to one or two specific geographical regions, and do not distinguish between possible mechanisms. We expect given the balance of the Chinese evidence and its limitations, and the near universally positive association found in Western societies and other Asian societies, that in the Chinese case:

\section{H1: Being religious is associated with a higher level of subjective wellbeing.}

\section{Public and Private Practice Mechanisms in the New China}

Western studies generally agree that religious adherents tend to have higher levels of wellbeing than the non-religious, and those that examine public and private aspects together find that it is the social capital resources, especially church-based networks and congregational groups, that explain this relationship. However, in the context of China, we expect that since religious networks and congregational groups are historically loose, relatively weak, and small-sized, they are unlikely to provide significant social resources, and so are an unlikely explanation for why wellbeing might be higher amongst adherents. First, major traditional religions in China (e.g., Buddhism, Daoism, and other folk religions) are generally non-congregational. On the one hand, the lack of established membership systems has allowed Chinese traditional religions to survive for centuries even though the Chinese authorities throughout history have regarded them as a potential threat to the political order (Yang 2006). On the other, the loosely organized systems of Chinese traditional religions mean that public aspects are much weaker than in the West. For example, Buddhist and Taoist believers normally do not belong to any particular temple or site of worship, and may frequent several temples, or practice at home. Unlike other religions where professional ecclesiastics actually minister to the laity (e.g. Catholic priests, Protestant pastors, or Islamic imams), Buddhist and Taoists monks generally do not interact directly with lay believers (Yang 2006).

Second, congregational religions that exist in China, such as Protestantism and Islam, have much smaller social network potential than in many Western countries. Although the prohibition of religion imposed during the Cultural Revolution was lifted in the 1980s, public religious practice is still under comparatively strict regulation. Church-based religions are relatively institutionalized, for instance, the China Protestant Three-Self Patriotic Movement Committee, the China Catholic Patriotic Committee, and the China Islamic Association, all officially represent the Christian and Islamic faith communities. The main functions of these are not only to organize religious activities but to help the party-state to implement its religious policies (Xing 2003). Consequently, as semi-official organizations, these religious bodies do not provide the same level of support networks as their counterparts might do in Western societies. Moreover, when it comes to smaller denominations and religions, these are generally not officially approved, so can only provide minimal and fragmented social network resources as well. For example, Palmer (2012) reports that 
a Bahá'í group divides when its membership reaches twenty. Protestant churches

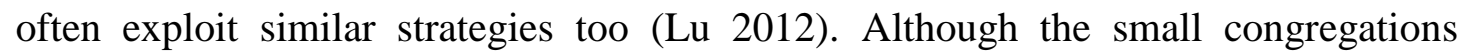
allows for frequent interaction, social networks of smaller size often lack the capacity to support their members materially or spiritually as compared to larger ones, so there is reason to believe "public aspects" will play a much smaller role in explaining the religious wellbeing gap in China. We also have other reasons to believe certain kinds of private aspects related to feelings a sense of self to play a prominent role in the Chinese context, which we outline next. Given the loose and small-scale nature of religious practice in China, we expect:

$\mathrm{H}$ 2: Private rather than public dimensions of religion matter more for the connection between being religious and subjective wellbeing.

\section{The Role of Subjective Status in the New China}

The high growth rate of religion in China can be interpreted as a mass psychological response to social anomie during times of great transition (Lu 2012). Given the well-documented rapid socioeconomic change in China, and weaker public aspects of religion, we therefore expect that private aspects, and particularly private aspects of a psychological kind, to be especially important in the Chinese context. China's growing inequality and fluid social mobility not only affects material socioeconomic conditions, but also feelings about them in terms of feelings of social standing. A large literature demonstrates a strong connection between subjective social status and wellbeing (e.g., Demakakos et al. 2008; Wolff et al. 2010; Kudrna et al. 2010; Destin et al. 2011). Several studies demonstrate that subjective social status is often a strong predictor of wellbeing even when objective markers of socioeconomic position such as education and income are controlled (Guven and Sørensen 2012; Rynko 2009; Anderson et al. 2012), highlighting the long-held sociological importance of the distinction between class and status (Weber 1953).

Additionally, there are multiple underlying mechanisms connecting status to wellbeing. For instance, Anderson et al. (2012) argue that the relationship between subjective social status and wellbeing is mainly driven by feelings of power and social acceptance, whilst Wilkinson and Pickett (2009) argue that feelings of lower status and perceptions of inferiority affect wellbeing by inducing feelings of shame and distrust. Numerous studies have shown that income inequality lowers perceptions of place in the social hierarchy in Western societies irrespective of personal income (Andersen and Curtis, 2012; Surridge, 2007; Curtis, 2014), resulting in status anxiety that tends to lower wellbeing in turn (Jackson 1962; Layte 2012; Treiman 1966; Wilkinson and Pickett 2005). In the Chinese context, feelings of status have been shown to be a particularly acute determinant of wellbeing, even when controlling for objective indicators of socioeconomic position (Zhao 2012). Existing survey evidence suggests particularly acute status anxiety in China (Chen and Fan 2015) and that this anxiety has been getting stronger as inequality has grown over the last two decades (Chen and Williams 2016). The connection between religion and feelings of status in determining wellbeing has not yet been established in China, however, despite the 
strong growth in religion and status anxiety over this period.

The relationship between religion and subjective social status has been partially established in Western societies, most notably the US. Hout (2008) finds that religious adherents tend to describe themselves as middle-class compared to the non-religious. Sosnaud et al. (2013) find that Black and Mainline Protestants are more likely to "inflate" their subjective class relative to what their objective characteristics. Steffen and Merrill (2011) report that Latter-day Saints amongst Mexican immigrants also tended to inflate their subjective class position. With respect to China, major religion traditions, such as Buddhism and Taoism, teach the virtues of tolerance, self-discipline, being unimpressed by power and money, or being above common people, and being free from vulgarity (Granet 1975; Liang 1989). By emphasizing non-material aspects of life, religious beliefs provide a strong sense of purpose and acceptance over and above one's (likely rapidly changing) material conditions. In Chinese culture, being religious is often linked with philanthropic giving and social responsibility, which can further improve self-concept (Du et. al. 2014). We conjecture that this "inflation" of social status by adherents stems from adherents being less sensitive to their socioeconomic conditions in determining their feelings of status than the non-religious, and that religious beliefs may buffer against life's anxiety and uncertainties. Indeed these qualities of the psychological aspect of religion could also explain part of religion's rise in China according to the religion market theory (Stark and Bainbridge 1987).

Since spiritual beliefs tend to lessen the value placed on material position (Inglehart 2010), we expect adherents to therefore hold higher feelings of status for a given level (objective) socioeconomic position (e.g., education or income) than the non-religious, especially given the rapid socioeconomic change in the context of China. And since subjective social status is such an important determinant of wellbeing in the Chinese context (Zhao 2012), we expect that subjective status could be a potentially important intervening variable accounting for any relationship between religion and wellbeing. However, to our knowledge, the relationship between religion and social status considered together as determinants of wellbeing has not yet been investigated. We conjecture adherents' sense of self stems more from spiritual beliefs instead of their socioeconomic environment. If this is the case, we expect that feelings of status should explain a large portion of any effect of religion on wellbeing, primarily because adherents tend to rate their status more highly irrespective of their material conditions due to lower sensitivity to them relative to the non-religious. To summarize, since religion offers a framework for interpretation of life, existential certainty, as well as self-efficacy, amongst adherents (Inglehart 2010), and especially compared to the non-religious in a context of rapidly growing inequality and status anxiety, we expect one potential mechanism why religion should predict wellbeing in China is through raising the subjective social status of adherents. Given this, our final hypothesis is:

$\mathrm{H} 3:$ The role of religion in wellbeing is mediated by subjective social status. 


\section{Data, Variables, and Analytic Strategy}

Data comes from the Chinese General Social Surveys (CGSS). The CGSS was initiated in 2003 jointly by the Survey Research Centre at Hong Kong University of Science and Technology and the Department of Sociology at Renmin University. It has become one of the most important sources of nationally representative data sources for the study of China. From 2010 to 2012, the CGSS interviewed 11,785, 5,620 , and 11,765 respondents respectively. Due to missing values on variables of interest, the effective pooled sample ends up comprising 23,255 respondents. Since urban residents are oversampled, we use sampling weights to compute representative figures for the general population in China. Table I presents the sample description.

\section{[Table I about here]}

Subjective wellbeing is captured by a single item asking respondents "Generally speaking, how happy do you feel about your life?", with five possible ordered responses: "very unhappy", "unhappy", "so-so", "happy", and "very happy". Although subjective wellbeing can normally be disaggregated into different life domains and it is important to recognise the multi-faceted nature of subjective wellbeing, studies show that different measures of subjective wellbeing, in particular life satisfaction and happiness, actually yield broadly consistent results in multivariate analyses (e.g., Helliwell and Putnam 2004; Abdel-Khaleka 2006). Given the wording of the wellbeing item we employ, it can be seen as pertaining to both life satisfaction and happiness. Table I shows approximately 76 per cent of respondents rate their feelings about their lives as "happy" or "very happy".

Being religious is captured by a question asking respondents whether they identify themselves as being either "non-religious" or "religious." Respondents reporting being religious were further asked to report the religion to which they belong. As shown in Table I, 13.39 per cent of respondents identify themselves as religious, in general consistent with other survey estimates (e.g., Lu 2012) and higher than official figures, as expected. Amongst believers, adherents of Buddhism, Protestantism, Islam, and Chinese folk religions account for almost 95 per cent, with Buddhism being the largest group (nearly 40 per cent). In our main analysis, we use a simple dummy to represent whether a respondent is religious or not, as in previous studies on China (e.g., Brown and Tierney 2009). In later analyses, we use a categorical measure to separately identify religious traditions. Our preferred specification is the single dummy because, as is common in other Asian societies, religious adherents often subscribe to more than one religion, so reading too much into religious affiliation could be problematic in the CGSS which only allows respondents to select one.

To examine the public or social capital dimension of religion, we first construct a general social capital indicator variable based on the reported frequencies of (1) "getting together with friends in the last year", (2) "getting together with relatives who do not live in the same house in the last year", and (3) "socializing in leisure time in the last year". For the first two items, respondents could select from five ordered 
responses: "never", "several times per year", "several times per month", "several times per week", and "everyday". For the third item, the responses were "never", "seldom", "sometimes", "often" and "always". Using factor analysis and varimax rotation, we obtain a unidimensional measure of general social capital from the two five-point ordinal scales. ${ }^{2}$

Since this social capital indicator does not specifically distinguish religious social capital from general social capital, we draw on a random subsample of 3,258 respondents selected from the 2010 sample who were asked several items on religion for additional analyses. ${ }^{3}$ This subsample was asked (1) "how often do you take part in activities at religious sites or with religious organizations?" and (2) "how often do you go to religious sites for religious reasons?" Possible responses range from 0 to 9 for the first item and 1 to 5 for the second item. ${ }^{4}$ These two items indicate frequencies of one's public involvement with religious groups and visiting religious sites respectively, which can be viewed as two indicators of religious social capital. In addition, these subsamples were also asked "how often do you pray?", a final item on private religious practice, similar to an item used in the "private/subjective" aspects of religion in Lin and Putnam's (2010) study. Possible responses for the private religious practice item range from 0 to $11 .^{5}$ Although analyses with these three items are based on a more limited sample, the trade-off is more specific measures of public and private aspects of religion.

To examine whether subjective status mediates any relationship between religion and wellbeing, we construct a scale based on three subjective social status items which ask respondents to position themselves socioeconomically compared to others in society by using the visual aid of a 10-rung ladder for the last 10 years, now, and 10 years in the future. We average the three measures of status perception to generate the overall subjective status for each respondent as the potential mediator, which is a continuous variable ranging from 1 to $10 .{ }^{6}$ Using a combined measure better captures the underlying construct as it relates more closely to the overall subjective wellbeing measure which may not only capture perceived wellbeing of the present, but also past and attitudes to future wellbeing. In the robustness check using just present subjective

\footnotetext{
2Factor analysis reveals a single underlying factor. The scale reliability coefficient (Chronbach's alpha) is 0.74 , showing a good internal reliability.

3 The CGSS 2010 randomly choose around 3,000 respondents to report extra religion-related information as part of a special module. Specifically, those who were born in March, May, July, and October.

4Possible responses for the first question is "never", "less than once per year", "one or two times per year", "several times per year", "around once per month", "two or three times per month", "almost every week", "every week", and "several times per week". Possible responses for the second question is "never", "less than once per year", "around one or two times per year, "several times per year" and "once per month or more".

${ }^{5}$ Possible responses for the first question is "never", "less than once per year", "one or two times per year", "several times per year", "around once per month", "two or three times per month", "almost every week", "every week", "several times per week", "once per day", and "several times per day".

${ }^{6}$ The Chronbach's alpha of the three measures is as high as 0.82 , demonstrating good internal consistency. We also performed a factor analysis and found that there was only one factor with Eigenvalue larger than 1 , accounting for $74.13 \%$ of the variance.
} 
status, we found that results are qualitatively very similar to using the aggregated measure.

Many other individual attributes that are associated with subjective wellbeing are also associated with holding religious beliefs, for example, age, gender, education, income, and health. Specific to the Chinese context, individual characteristics such as Chinese Communist Party (CCP) membership (members are forbidden from being religious) or residential status (as some religious populations are geographically concentrated and dispersed) may contribute to both religion and subjective wellbeing. We therefore control for demographic characteristics (age, gender, years of schooling, marital status, health status, and ethnicity); socioeconomic factors (residential status, work status, CCP membership, individual annual income, and family annual income); and for wave (year) and province dummies.

Table I demonstrates that in general religious adherents are more likely to be female, rural residents, less educated, and older than the non-religious. Ethnic minorities are also more likely to be religious given the close relationship between religion and ethnic identity (Liu and Zhang 2012). It is notable that adherents have higher average level of social capital resources than their non-religious peers, suggesting that religious attendance or practices may help to build social networks. Also notable is that religious adherents have a higher opinion of their social status compared to the non-religious.

Given that wellbeing is measured on a five-point scale, we use ordered probit regression as it relaxes the assumption that the intervals between points on the wellbeing scale are equal. We also adjust standard errors for regional clustering. The analysis proceeds in five steps: First, we first examine whether being religious is associated with higher levels of wellbeing, adjusting for possible confounders. Second, to test if the public dimension of religion matters in China, we introduce the general and religious social capital indicators to examine whether they mediate the effect of religion on wellbeing. ${ }^{7}$ Third, we examine the predictive power of religion on subjective social status, and then incorporate the subjective social status score into the wellbeing analysis too. ${ }^{8}$ Fourth, as a robustness check on the omitted variable problem, we adopt an instrumental variable approach of the first three steps. Finally, we proceed to a more disaggregated analyses on the roles of specific religious traditions.

\section{Results}

\section{The relationship between religion and wellbeing}

Table II starts with a baseline model including the religious dummy and the sets of

\footnotetext{
${ }^{7}$ Directly comparing uncontrolled and controlled coefficients between nested non-linear models is problematic because the scale parameter of the error terms of a full model is smaller than that of a reduced model. To remedy this, we adopt the solution proposed by Karlson, Holm and Breen (2011) to decompose the coefficient change into a part of mediation effects and a differences in scale parameter part.

${ }^{8} \mathrm{We}$ do so by perform a full Sobel-Goodman Test.
} 
demographic and socioeconomic controls. According to the average partial effects ${ }^{9}$ reported in Model 1, consistent with earlier findings, we find a U-shaped relationship between age and wellbeing. We also find that gender, years of schooling, ethnicity, residential status, employment status, family income, CCP membership, and health, all significantly predict subjective wellbeing. Importantly, holding other factors constant, being religious increases the probability of being very happy (the top category) by around 1.5 per cent. This finding supports H1. Although the magnitude of the association appears small, comparing it to the average partial effects of other variables of substantive importance, the relative magnitude of religion becomes clearer: It is larger than the difference between unemployed and employed respondents, and almost comparable to the difference between rural residents and rural-to-urban migrants. Bearing in mind that in China, residential status is assigned by authorities through a household registration system known as hukou (which ties access to jobs, education, housing, and healthcare to the specific locality where one has been assigned residency) it greatly contributes to the urban-rural divide ( $\mathrm{Wu}$ and Treiman 2004; Wu 2011) as it denies rural-to-urban migrants (migrants from rural areas living in cities) access to these amenities in the city in which they now reside. The effect of religion on wellbeing in China is therefore non-trivial.

\section{[Table II about here]}

\section{The roles of social capital, public, and private aspects}

Since social networks and resources may potentially explain the association between religion and wellbeing, we next examine the role of the social capital mechanisms in Model 2 of Table II, extending Model 1 by including the general social capital indicator. As shown in Model 2, although general social capital significantly predicts wellbeing, controlling for it does not substantially attenuate the role of being religious. To some extent, this may imply that the public aspects of religion do not explain the relationship between being religious and subjective wellbeing, providing some support for H2. However, as stated earlier, this social capital measure is of a very general kind, whereas arguments about the public aspects of religion have tended to focus specifically on religious social capital. In Table III, we therefore include the more specific indicators of public and also private aspects of religion featured in the special 2010 subsample, controlling for the same covariates as those in Table II (although we only report the average partial effects of key variables). We first introduce frequency of vising religious sites in Model 1, and then the frequency of public involvement with religious groups in Model 2. Neither of these two measures of public aspects of religion are found to be statistically significant predictors of wellbeing. Model 3 includes the general social capital indicator, which continues to positively predict wellbeing. Model 4 further includes the indicator of private religious practice. Controlling for both general and religious social capital, private

\footnotetext{
${ }^{9}$ Average partial effects are probit coefficient estimates that have been adjusted so they are interpretable on a probability scale.
} 
religion practice, as measured by the frequency of praying, is found to positively predict wellbeing, strongly suggesting that it is the private rather than public dimension of religion matter more to subjective wellbeing in China. ${ }^{10}$ We thus find support for $\mathrm{H} 2 .^{11}$

\section{[Table III about here]}

\section{The mediating role of subjective status}

As for the hypothesised social status mechanism, and its potential explanatory role, Model 3 in Table II includes subjective social status instead social capital. The results show that, having included self-rated status, the apparently significant role of religion is no longer statistically significant. This implies that subjectively perceived social status substantially mediates the religious-non-religious gap in wellbeing. The average partial effect of subjective status (0.041) is substantively large and significant, corroborating previous research on status determining wellbeing in China (Zhao 2012). The magnitude of this association is substantively large: greater than the roles of gender, ethnicity, and CCP membership - and almost comparable to the difference between being divorced/widowed and married. Model 4 controls for both general social capital and subjective social status together, and the results suggest that status continues to mediate the role of religion, providing preliminary support for $\mathrm{H} 3$.

To better understand the relationships between religion, social status, and wellbeing we explore different specifications with different combinations of wellbeing predictors in Table IV. The first two models include only religion (Model 1) or subjective status (Model 2) as predictors of wellbeing, with no other (objective socioeconomic) factors partialled out. We find both positively predict wellbeing when no other factors are controlled. Model 3 includes both religion and subjective status together, with no other controls. Here too we find that both religion and subjective status independently predict wellbeing. This is different to what was found in Table II in that subjective status mediated the role of religion on wellbeing. This is because the interpretation of social status is sensitive to other controls in the model as the predictive role of social status on wellbeing without controls captures some of the information in the controls i.e. reflections of status are partially based upon objective socioeconomic conditions. Once we control for these other socioeconomic factors in

\footnotetext{
${ }^{10}$ Note that even when general social capital is interacted with detailed religious denominations, no evidence is found for differences across religions, implying the lack of mediation by general social capital is not due to variation across religion traditions i.e. traditionally more congregational vs. traditionally less congregational regions. Similarly, we find little difference in the role of general social capital between rural and urban areas across religions groups, even though congregational religions in rural areas might monitored less by the state as compared to urban areas, again suggesting that little evidence can be found for public aspects (results available on request). We thank an anonymous reviewers for making these suggestions.

${ }^{11}$ Note that praying, which may be considered a private aspect, does not mediate the effect of subjective social status on wellbeing either (results available on request).
} 
Model 4 in Table IV (which is exactly the same as Model 4 in Table II), subjective status continues to be independently predictive of wellbeing (although the coefficient is smaller). However, the effect of religion now drops to insignificance. This indicates that the effect of religion on wellbeing, then, is partially mediated by the joint inclusion of both (objective) socioeconomic factors and reflections of these conditions (i.e. subjective status) together. For completeness, Model 5 includes religion and all controls but not subjective status, and we find that religion is predictive of wellbeing in this case. We interpret this as demonstrating that including objective indicators of socioeconomic position controls for their influence on self-rated status, and as such, is an indicator of status feelings net of these. In summary, we interpret the pattern of results in Table IV as demonstrating that adherents' status feelings when material factors are controlled to become an indicator of sense which is independent of personal material conditions. In other words, adherents have higher feelings of status for a given set of socioeconomic factors, and it is this that explains why they report higher levels of wellbeing.

\section{[Table IV about here]}

We investigate this logic in more detail by fitting OLS models predicting subjective social status to explore the role of religion in determining it, controlling for all the variables used in the models predicting wellbeing. The results in Table $\mathrm{V}$ demonstrate that being religious is significantly associated with nearly 0.1 points higher self-rated status, net of controls. The magnitude of the effect of being religious on status is comparable to the difference in average subjective social status between rural residents and rural-to-urban migrants. This suggests the religious wellbeing gap can be, if only partially, explained by the higher self-rated status of adherents. Or to put it another way, for a given level of objective socioeconomic position, religious adherents rate their status more highly than the non-religious. This is also consistent with previous Western research that demonstrates adherents tend to "inflate" their social status. We further argue that, at least in the Chinese context, this is because religious beliefs act as a buffer to socioeconomic conditions in determining self-rated social status, in effect making adherents less sensitive to their material conditions in determining their status, and so wellbeing. As such feelings of status, net of material conditions, explain why a religious wellbeing gap exists in China.

\section{[Table $\mathrm{V}$ about here]}

To test whether the mediating role of subjective social status on religion predicting wellbeing is robust, we further conduct a full Sobel-Goodman analysis (Sobel 1986) which apportions the amount of the effect of religion on wellbeing that is explained by the effect of social status on religion. As is shown in Table VI, the mediation effect of subjective social status is statistically significant with approximately $40.26 \%$ of the total effect of being religious on wellbeing being mediated by feelings of social status. Taken together, all of these results indicate 
support for $\mathrm{H} 3$ by revealing that subjective social status accounts for a large fraction of the effect of religion on wellbeing.

\section{[Table VI about here]}

\section{The issue of reverse causality}

Given that our data are cross-sectional, the relationship between religion and wellbeing could run the other way - perhaps people with already higher levels of wellbeing are more likely to adopt religion. In the absence of longitudinal data, we provide a robustness check on this interpretation using the historical density of religious sites as an instrumental variable (IV) for being religious. Specifically, using the novel data from Spatial Explorer of Religion, ${ }^{12}$ a geographic information system jointly developed by Purdue University, University of Michigan, and Wuhan University, we obtain the provincial-level numbers of all temples, churches, mosques, and abbeys built between 210CE to 1949, just before the CCP came into power. We standardize the numbers using the area of each province to obtain the provincial density of religious sites just before 1949 (with a mean value of 8 religious sites per kilometer square, ranging from 0.34 to 51 ). The IV, the historical density of religious sites at the provincial level, is correlated with the respondent's own religion because previous research finds that religion is contagious and linked to historical local identity (Stark and Finke 2004). And, as a historical and aggregate-level factor before the CCP came into power, the IV should not directly affect individual wellbeing in contemporary China.

To perform IV-OProbit analysis, we simultaneously estimate a probit selection model (with religion as the dependent variable) and an ordered probit model (with wellbeing as the dependent variable). The estimates and key statistics are reported Model 5 in Table II. The $Z$ values are big enough to pass the weak IV test, meaning our IV is strongly correlated with religion. ${ }^{13}$ Consistent with what was found in Model 4, the IV estimates show that the role of being religious is mediated by subjective social status (although not reported here, estimates obtained from an IV model excluding subjective status show that the partial role of religion in wellbeing is positive and significant). Note that the statistically insignificant "atanh-rho" (the inverse hyperbolic tangent of the correlation between the error term of the substantial regression equation and the error term of the selection equation) suggests that we cannot reject the null hypothesis of exogeneity, and therefore we can adopt the original ordered probit estimates in Table II, which are more efficient. However, it must be noted that, the IV is not perfect, as there could be ways in which historical religiosity of a province could be tied in with historical economic development, and so feelings of social status and wellbeing many years later. However, the fact that the

12 The first release of the "Spatial Explorer of Religion" data can be accessed at http://chinadataonline.org/religionexplorer.

13 We report the $\mathrm{Z}$ value of the IV in the selection equation to show the strong association between endogenous variable and the IV. We also derived the F-statistics from linear-probability selection model with religion as a continual dependent. The Cragg-Donald Wald F statistic is 593, and Kleibergen-Paaprk Wald F statistic is 36.584. 
50 per cent of the sites of worship in the Spatial Explorer of Religion existed before 1903, with one-quarter existing before 1828 , their correlations with present-day status and wellbeing should be somewhat mitigated.

\section{Variation across religious traditions}

Finally, in Table VII we present results disaggregating different religion traditions. Given that the numbers of adherents of Daoism, Catholic, Orthodox, and other Christianity denominations are very small, we collapse these. We code religious affiliation into five categories: Non-religious, Buddhism, Protestantism, Islam, Chinese folk religion, and the residual category for the numerically small religions. ${ }^{14}$ Note that, small sample numbers aside, such a disaggregated analyses is at best provisional because many Chinese religious believers adopt multiple religions, but nonetheless, variation in the strength of religion on wellbeing aids interpretation of the findings uncovered thus far.

The estimates in Model 1 of Table VII demonstrate that adherents of Buddhism and Protestantism tend to have higher levels of wellbeing compared to the non-religious. But the effects of adherents of other religious denominations are not statistically significant, although they are in the same direction. The one exception is the residual category, which is negative but nonsignificant. This could partly be due to small sample numbers and the heterogeneous nature of this group. Even still, since Buddhists and Protestants account for more than half of the religious population in China, the overall effect of religion is a positive one, as demonstrated in Table II.

\section{[Table VII about here]}

Importantly, since Protestantism is more congregational than Buddhism, even in China, it follows then that adding general social capital into the model should reduce the magnitude of the role of Protestantism to a greater extent than that of Buddhism. However, in Model 2 in Table VII, controlling for general social capital, the average partial effect of Protestantism decreases only very slightly from .028 to .027 and remains significant, whilst the average partial effect of Buddhism also very slightly drops from .021 to .020 . Model 3 shows that introducing subjective social status substantially reduces the magnitude of the effects of Buddhism and to a lesser extent Protestantism on wellbeing, making both their roles nonsignificant. The larger mediating effect on Buddhism could perhaps be connected to stronger beliefs regarding the denouncement of material cravings (Harvey 2012), of which similar themes do exist for Protestantism, but are perhaps less central and are more theistically-driven. Indeed, in other analyses (not shown) controlling for other factors, we find that Buddhism more strongly predicts subjective status than Protestantism, although both significantly and positively predict it. Finally, introducing social capital in Model 4 barely alters these associations.

14 Although not reported here, we used the original more detailed categorical variable and found that the partial effects of Chinese folk religion, Daoism, Catholic, Orthodox, and Other Christianity are all individually insignificant. 


\section{Conclusions}

Results from Western societies are generally supportive of a relationship between religion and subjective wellbeing. Representative evidence on this relationship does not exist for China, which presents us with a rather different and interesting context. We find that, in China, religious adherents generally have higher wellbeing than the non-religious as is found in Western contexts. Importantly, we shed light on why this positive association comes about in terms of the public versus private dimensions of religion. Contradicting previous Western studies, which tend to find more support for public aspects of religion as opposed to the private aspects (e.g., Clark and Lelkes 2009; Lim and Putnam 2010), we find little support for public aspects such as social capital resources and frequency of interaction. In contrast, we find private religious practices such as praying do matter for wellbeing. Most importantly, we investigated a more appropriate mechanism to the Chinese context: religion increases adherents sense of self, and this in turn explains why a religion wellbeing gap exists in the New China, where rapid socioeconomic change and urbanization has led to acute status anxiety.

We have shown that being religious is approximately as important as the effect of employment status or the social inequality of the household registration system. Taken together, our findings could perhaps explain some of the high growth rate in the number of adherents in China at a time of immense economic, social, and political change. The rise of religion can be seen as a response to social anomie: it raises the wellbeing of adherents by improving self-rated status on a social ladder where the rungs are rapidly growing further apart. This article extends the scope of previous literature beyond the Western societies to incorporate mainland China, shedding light on our understanding of mechanisms connecting religion to wellbeing in the course of a transition from a state-planned to market economy. The findings in this study on China strongly suggest that the effects of religion on individual outcomes are to great extent defined, not only by religious context, but by the wider cultural and political environments, and in particular, acute Chinese status anxiety. We do not rule out this finding as unique to China and highlight it as an area for future research.

Even though our results suggest religion affects wellbeing in China through feelings of social status at a time of great status anxiety, and not through public religious practices, this does not mean that with an ever increasing religious population and improving religious freedoms, public aspects will not become more important in the future. Since the resurgence in religion is a relatively recent phenomenon, it is reasonable to suggest that public aspects may become more important. There might be some tipping point ahead where the effects of the public aspects of religions emerge more important than the private aspects and feelings of status, as in the West, to which this article provides the first step as the New China continues to march forward.

\section{REFERENCES}


Abdel-Khaleka, Ahmed M. 2006. "Measuring Happiness with a Single-item Scale". Social Behavior and Personality 34: 139-150.

Anderson, Cameron, Michael W. Kraus, Adam D. Galinsky, and Dacher Keltner. 2012. "The Local-Ladder Effect: Social Status and Subjective Well-Being." Psychological Science. 23(7): 764-71.

Andersen, Robert, and Josh Curtis. 2012. "The polarizing effect of economic inequality on class identification: Evidence from 44 countries." Research in Social Stratification and Mobility. 30: 129-141

Brooks, Arthur. C. 2008. Gross national happiness: Why Happiness Matter for AmericaAnd How We Can Get More of It. New York: Basic Books.

Brown, Philip H. and Brian Tierney. 2009. "Religion and Subjective Well-being among the Elderly in China." The Journal of Socio-Economics 38(2): 310-319.

Campbell, Angus, Philip E. Converse, and Willard L. Rodgers. 1976. The Quality of American Life: Perceptions, Evaluations, and Satisfactions. New York: Russell Sage Foundation.

Chen, Yunsong, and Xiaoguang Fan, 2015, "Discordance between Subjective and Objective Social Status in Contemporary China ", The Journal of Chinese Sociology Vol 2(14):1-13.

Chen, Yunsong, and Mark Williams, 2016, "Subjective Social Status in Transitioning China: Trends and Determinants." Social Science Quarterly (Forthcoming)

Clark, Andrew E. and Orsolya Lelkes. 2006. "Deliver us from evil: Religion as insurance." European Network on the Economics of Religion, PER 06/03.

--- 2009. "Let Us Pray: Religious Interactions in Life Satisfaction." PSE Working Papers 2009-01.

Curtis, Josh. 2014. "Mobility and Class Identity in 35 Societies: The Role of Economic Conditions". European Sociological Review (R\&R).

Demakakos, Panayotes, James Nazroo, Elizabeth Breeze, and Michael Marmot. 2008. "Socioeconomic Status and Health: The Role of Subjective Social Status. Social Science and Medicine. 67: 330-340.

Dolan, Paul, Tessa Peasgood, and Mathew White. 2008. "Do We Really Know What Makes Us Happy? A Review of the Economic Literature on the Factors Associated with Subjective Well-being." Journal of Economic Psychology. 29(1): 94-122.

Du, Xingqiang, Wei Jian, Yingjie Du, Wentao Feng, and Quan Zeng, 2014. "Religion, the Nature of Ultimate Owner, and Corporate Philanthropic Giving: Evidence from China." Journal of Business Ethics. 123(2):235-256.

Ellison, Christopher G., Jason D. Boardman, David R. Williams, and James S. Jackson. 2001. "Religious Involvement, Stress, and Mental Health: Findings from the 1995 Detroit Area Study." Social Forces 80: 215-249.

Ellison, Christopher G., Amy M. Burdette, and Terrence D. Hill, 2009. "Blessed assurance: Religion, anxiety, and tranquility among US adults." Social Science Research, 38(3), pp. 656-667.

Ferriss, Abbott L. 2002. "Religion and Quality of Life." Journal of Happiness Studies. 3: 199-215.

Frey, Bruno S. and Alois Stutzer 2002. Happiness and Economics: How the Economy and 
Institutions Affect Well-Being. Princeton and Oxford: Princeton University Press.

Granet, Marcel 1975. The Religion of the Chinese People. New York: Harper Torchbooks.

Greeley, Andrew and Michael Hout. 2006. "Happiness and Lifestyle among Conservative Christians." In The Truth about Conservative Christians. Chicago, IL: University of Chicago Press, pp. 150-61.

Gruber, Jonathan. 2005. "Religious Market Structure, Religious Participation, and Outcomes: Is Religion Good for You?" Advances in Economic Analysis and Policy 5(1): 1445-1454.

Guven, Cahit and Bent E. Sørensen. 2012. "Subjective Well-Being: Keeping Up with the Perception of the Joneses." Social Indicators Research. 109(3): 439-69.

Harvey, Peter. 2012. An Introduction to Buddhism: Teachings, History, and Practices (Second Edition). Cambridge: Cambridge University Press.

Hayward, R. D. \& Krause, N. 2014. Religion, mental health and well-being: Social aspects. In V. Saroglou (Ed.), Religion, Personality, and Social Behavior (pp. 255-280). New York: Psychology Press.

Helliwell, John F. and Robert D. Putnam. 2004. "The Social Context of Well-Being." Philosophical Transactions of the Royal Society B: Biological Sciences 359:1435 46.

Hout, Michael. 2008. "How Class Works in Popular Conception: Most Americans Identify with the Class Their Income, Occupation, and Education Implies for Them." Ch. 2 in Annette Lareau and Dalton Conley (Eds.) Social Class: How Does It Work? New York: Russell Sage Foundation.

Inglehart, Ronald F. 2010. "Faith and Freedom: Traditional and Modern Ways to Happiness." In E. Diener, J. F. Helliwell, and D. Kahneman (eds.), International Differences in Well-Being. New York: Oxford University Press, pp. 351-397.

Jackson, Elton F. 1962. "Status Consistency and Symptoms of Stress." American Sociological Review. 27 (August): 469-80.

Karlson, KB., A. Holm, and R. Breen. 2012. "Comparing regression coefficients between same-sample nested models using logit and probit a new method." Sociological Methodology, 42(1): 286-313.

Layte, Richard. 2012. "The Association Between Income Inequality and Mental Health: Testing Status Anxiety, Social Capital, and Neo-Materialist Explanations”. European Sociological Review. 28 (4):498-511

Liang, Shuming, 1989. A Comparison of Confucianism and Buddhism. Contemporary Chinese Thought. 20 (3):3-32.

Lim, Chaeyoon and Robert D. Putnam. 2010. "Religion, Social Networks, and Life Satisfaction." American Sociological Review. 75(6): 914-933.

Liu, Eric Y. 2009. "Beyond the West: Religiosity and the Sense of Mastery in Modern Taiwan." Journal for the Scientific Study of Religion 48(4): 774-788.

Liu, Eric Y., Harold G. Koenig, and Dedong Wei. 2012. "Discovering a Blissful Island: Religious Involvement and Happiness in Taiwan." Sociology of Religion. 73 (1): 4668.

Liu, Siyong and Xuesong Zhang 2012, The Population and Distribution of Muslims in Modern China, World Religious Culture (shi jie zong jiao wen hua), vol 4. (in 
Chinese).

Lu, Yunfeng. 2012. "Understanding the Rise of Religion in China". Chinese Sociological Review 45(2):3-7.

Norris, Pippa and Ronald Inglehart. 2004, Sacred and Secular. Religion and Politics Worldwide. Cambridge University Press.

Palmer, David A. 2012. "From 'Congregations' to 'Small Group Community Building': Localizing the Bahá'í Faith in Hong Kong, Taiwan and Mainland China." Chinese Sociological Review. 45(2): 38-49.

Potter, Pitman B. 2003. "Belief in Control: Regulation of Religion in China." In Daniel L. Overmyer (ed.), Religion in China Today. New York: Cambridge University Press, pp. $11-31$.

Rynko, Maja. 2009. "Income, Relative Social Status and the Determinants of Happiness in Europe. Working Paper, European University Institute.

Snoep, Liesbeth. 2008. "Religiousness and Happiness in Three Nations: A Research Note." Journal of Happiness Studies. 9(2): 207-211.

Sobel, Michael E. 1986/ "Some new results on indirect effects and their standard errors in covariance structure models." Sociological Methodology, 16:159-186.

Sosnaud, Benjamin, David Brady, and Steven M. Frenk. 2013. "Class in Name Only: Subjective Class Identity, Objective Class Position, and Vote Choice in American Presidential Elections." Social Problems 60(1): 81-99.

Stark, Rodney, and William S. Bainbridge. 1987. A Theory of Religion. New York: Peter Lang.

Stark, Rodney, and Roger Finke. 2000. Acts of Faith: Explaining the Human Side of Religion. Berkeley: University of California Press.

--- 2004. "Religions in Context: The Response of Non-Mormon Faiths in Utah." Review of Religious Research 45: 293-298.

Stark, Rodney and Eric Y. Liu. 2011. "The Religious Awakening in China." Review of Religious Research 52(3): 282-289.

Steffen, Patrick and Ray Merrill. 2011. "The Association Between Religion and Acculturation in Utah Mexican Immigrants." Mental Health, Religion and Culture 14(6): 561-573.

Steger, Michael F., and Patricia Frazier. 2005. Meaning in Life: One Link in the Chain From Religiousness to Well-Being. Journal of Counseling Psychology, 52(4), 574-582.

Surridge, Paula, 2007. "Class belonging: A quantitative exploration of identity and consciousness," British Journal of Sociology, 58(2):207-226.

Swinyard, William R., Ah-Keng Kau, and Hui-Yin Phua. 2001. "Happiness, Materialism, and Religious Experience in the U.S. and Singapore." Journal of Happiness Studies 2: $13-32$.

Treiman, Donald J. 1966. "Status Discrepancy and Prejudice." American Journal of Sociology. 6 (May): 651-664.

US Department of State. 2010. "Report on Religious Freedoms: China." URL: http://www.state.gov/j/drl/rls/irf/2010/148863.htm [accessed 2/02/15].

Wang, Xumei, Ting Wang, and Buxin Han. 2012. "The Mental Health of Older Buddhists 
After the Wenchuan Earthquake." Pastoral Psychology 61(5-6): 841-850.

Weber, Max. 1953. "Ch VII: Class, Status, Party." In Hans H. Gerth and C. Wright Mills (Eds.). From Max Weber: Essays in Sociology. New York: Oxford University Press.

Wei, Dedong and Eric Y. Liu. 2013. "Religious Involvement and Depression: Evidence for Curvilinear and Stress-Moderating Effects among Young Women in Rural China." Journal for the Scientific Study of Religion 52(2): 349-367.

Wilkinson, Richard G. 2005. The Impact of Inequality: How to Make Sick Societies Healthier. New York: New Press.

Wilkinson, Richard G., and Kate E. Pickett. 2009. "Income Inequality and Social Dysfunction". Annual Review of Sociology, 35: 493-511.

Wolff, Lisa S., Sukanya V. Subramanian, et al. 2010. "Compared to Whom? Subjective Social Status, Self-rated Health, and Referent Group Sensitivity in a Diverse US Sample." Social Science and Medicine 70: 2019-202.

Wu, Xiaogang. 2011. "The Household Registration System and Rural-Urban Educational Inequality in China." Chinese Sociological Review, 44(2): 31-51.

Wu, Xiaogang and Donald, J. Treiman. 2004. "The Household Registration System and Social Stratification in China: 1955-1996." Demography, 41(2): 363-384.

Xing, Fuzeng. 2003. "Church-state Relations in Contemporary China and the Development of Protestant Christianity." China Study Journal 18(3): 19-48.

Yang, Fenggang. 2006. "The Red, Black, and Gray Markets of Religion in China." The Sociological Quarterly 47: 93-122.

----- 2011. Religion in China: Survival and Revival under Communist Rule. New York: Oxford University Press.

Zhao, Wei. 2012. "Economic inequality, status perceptions, and subjective well-being in China's transitional economy." Research in Stratification and Mobility. 30(4): 433-450. 


\section{TABLES}

Table I. Selected descriptive statistics of pooled sample, 2010-2012

\begin{tabular}{|c|c|c|c|c|}
\hline \multicolumn{2}{|l|}{ Variables } & \multirow{2}{*}{$\begin{array}{l}\text { Total } \\
1.75\end{array}$} & \multirow{2}{*}{$\begin{array}{l}\text { Religious } \\
2.19\end{array}$} & \multirow{2}{*}{$\begin{array}{l}\text { Non-religious } \\
1.68\end{array}$} \\
\hline Subjective Wellbeing & Very unhappy & & & \\
\hline & Unhappy & 7.01 & 7.83 & 6.89 \\
\hline & So-so & 14.86 & 13.62 & 15.05 \\
\hline & Happy & 59.03 & 53.10 & 59.95 \\
\hline & Very happy & 17.35 & 23.27 & 16.43 \\
\hline \multirow[t]{3}{*}{ Marital Status } & Married & 86.17 & 84.82 & 86.37 \\
\hline & Single & 6.97 & 9.27 & 6.61 \\
\hline & Divorced/widowed & 6.87 & 5.91 & 7.02 \\
\hline \multirow[t]{3}{*}{ Work Status } & Unemployed & 15.76 & 17.40 & 15.50 \\
\hline & Employed & 70.28 & 69.81 & 70.35 \\
\hline & Never worked/retired & 13.97 & 12.79 & 14.15 \\
\hline \multirow[t]{3}{*}{ Residential Status } & Rural residents & 46.96 & 47.22 & 46.92 \\
\hline & Urban residents & 37.72 & 33.11 & 38.43 \\
\hline & Rural-to-urban migrants & 15.32 & 19.67 & 14.64 \\
\hline \multirow[t]{5}{*}{ Health Condition } & Very unhealthy & 4.98 & 5.89 & 4.83 \\
\hline & Unhealthy & 19.06 & 20.43 & 18.84 \\
\hline & So-so & 23.08 & 22.23 & 23.21 \\
\hline & Healthy & 32.83 & 31.56 & 33.03 \\
\hline & Very healthy & 20.06 & 19.90 & 20.09 \\
\hline \multirow[t]{10}{*}{ Religious Traditions } & Buddhism & & 37.26 & \\
\hline & Chinese folk religion & & 22.85 & \\
\hline & Islam & & 20.85 & \\
\hline & Protestant Christianity & & 14.76 & \\
\hline & Daoism & & 2.02 & \\
\hline & Catholic Christianity & & 1.49 & \\
\hline & Orthodox Christianity & & 0.04 & \\
\hline & Other Christianity & & 0.05 & \\
\hline & Other religions & & 0.69 & \\
\hline & Any religion (total) & 13.39 & 100 & \\
\hline \multicolumn{2}{|l|}{ Male } & 51.92 & 43.99 & 53.15 \\
\hline \multicolumn{2}{|l|}{ Han Chinese (ethnicity) } & 90.84 & 71.46 & 93.84 \\
\hline \multicolumn{2}{|l|}{ CCP Member } & 12.94 & 0.08 & 13.74 \\
\hline \multicolumn{2}{|l|}{ Age } & $47.61(14.96)$ & $48.18(15.34)$ & $47.53(14.91)$ \\
\hline \multicolumn{2}{|l|}{ Years of Schooling } & $8.44(4.43)$ & $7.42(4.38)$ & $8.60(4.42)$ \\
\hline \multicolumn{2}{|c|}{ Individual Annual Income (yuan) } & $18,372(56,572)$ & $17,748(50,935)$ & $18468(57,395)$ \\
\hline \multicolumn{2}{|c|}{ Family Annual Income (yuan) } & $45,099(95,851)$ & $45,574(87,818)$ & $45027(97,036)$ \\
\hline \multicolumn{2}{|l|}{ Social Capital } & $-0.004(1.02)$ & $0.010(1.09)$ & $-0.006(1.02)$ \\
\hline \multicolumn{2}{|l|}{ Subjective Social Status } & $4.302(1.61)$ & $4.45(1.66)$ & $4.28(1.60)$ \\
\hline \multicolumn{2}{|l|}{$\mathrm{N}$} & 23,255 & 3,113 & 20,142 \\
\hline \multicolumn{5}{|c|}{ Extra religious variables in the CGSS 2010} \\
\hline \multicolumn{2}{|l|}{ Visiting Religious Sites } & $1.493(1.030)$ & $2.980(1.538)$ & $1.246(.646)$ \\
\hline \multicolumn{2}{|c|}{ Involvement with religious groups } & $1.407(1.278)$ & $3.279(2.451)$ & $1.096(.478)$ \\
\hline \multicolumn{2}{|c|}{ Private Religious Practice (Praying) } & $1.535(.1888)$ & $4.326(3.787)$ & $1.072(.522)$ \\
\hline \multicolumn{2}{|l|}{$\mathrm{N}$} & 3,258 & 2,794 & 464 \\
\hline
\end{tabular}

Notes Percentages for categorical variables and means for continuous variables reported; numbers in parentheses are standard deviations. Data are weighted. 
Table II. The determinants of wellbeing in China, 2010-2012

\begin{tabular}{|c|c|c|c|c|c|}
\hline & $\begin{array}{l}\text { Model } 1 \\
\text { Oprobit }\end{array}$ & $\begin{array}{c}\text { Model } 2 \\
\text { Oprobit }\end{array}$ & $\begin{array}{l}\text { Model } 3 \\
\text { Oprobit }\end{array}$ & $\begin{array}{c}\text { Model } 4 \\
\text { Oprobit }\end{array}$ & $\begin{array}{c}\text { Model } 5 \\
\text { IV-Oprobit }\end{array}$ \\
\hline Age & $-.007(.001)^{* * *}$ & $-.007(.002)^{* * *}$ & $-.005(.001)^{* * *}$ & $-.005(.001)^{* * *}$ & $-.005(.001)^{* * *}$ \\
\hline Age-Squared / 100 & $.009(.001)^{* * *}$ & $.009(.001)^{* * *}$ & $.008(.001)^{* * *}$ & $.008(.001)^{* * *}$ & $.008(.001)^{* * *}$ \\
\hline Male & $-.030(.004)^{* * *}$ & $-.031(.004)^{* * *}$ & $-.020(.004)^{* * *}$ & $-.020(.004)^{* * *}$ & $-.021(.004)^{* * *}$ \\
\hline Years of Schooling & $.003(.0007)^{* * *}$ & $.002(.0007)^{* * *}$ & $.001(.0007)$ & $.001(.0007)$ & $.001(.0007)$ \\
\hline Han Chinese & $-.025(.009)^{* *}$ & $-.024(.009)^{* *}$ & $-.022(.009)^{*}$ & $-.022(.009)^{*}$ & $-.022(.009)^{*}$ \\
\hline CCP Member & $.040(.005)^{* * *}$ & $.038(.006)^{* * *}$ & $.032(.006)^{* * *}$ & $.031(.006)^{* * *}$ & $.031(.006) * * *$ \\
\hline Individual Annual Income & $-.00002(.0008)$ & $-.00002(.0008)$ & $-.0004(.0007)$ & $-.0004(.0008)$ & $-.0003(.0008)$ \\
\hline Family Annual Income & $.033(.002)^{* * *}$ & $.031(.002)^{* * *}$ & $.022(.006)^{* * *}$ & $.021(.002)^{* * *}$ & $.021(.002) * * *$ \\
\hline \multicolumn{6}{|l|}{ Marital Status } \\
\hline Single & $-.083(.008)^{* * *}$ & $-.083(.008) * * *$ & $-.075(.007)^{* * *}$ & $-.076(.007)^{* * *}$ & $-.068(.006)^{* * *}$ \\
\hline Divorced/widowed & $-.057(.009) * * *$ & $-.057(.009) * * *$ & $-.055(.009) * * *$ & $-.055(.009)^{* * *}$ & $-.052(.008)^{* * *}$ \\
\hline \multicolumn{6}{|l|}{ Health Condition } \\
\hline Unhealthy & $.071(.013) * * *$ & $.069(.013)^{* * *}$ & $.055(.012)^{* * *}$ & $.055(.012)^{* * *}$ & $.038(.008)^{* * *}$ \\
\hline So-so & $.112(.012)^{* * *}$ & $.111(.012)^{* * *}$ & $.089(.011)^{* * *}$ & $.088(.011)^{* * *}$ & $.066(.008)^{* * *}$ \\
\hline Healthy & $.159(.013) * * *$ & $.155(.013) * * *$ & $.126(.012)^{* * *}$ & $.124(.012)^{* * *}$ & $.101(.009)^{* * *}$ \\
\hline Very healthy & $.237(.014)^{* * *}$ & $.232(.014) * * *$ & $.196(.012)^{* * *}$ & $.193(.013)^{* * *}$ & $.183(.011)^{* * *}$ \\
\hline \multicolumn{6}{|l|}{ Work Status } \\
\hline Employed & $.010(.006)$ & $.009(.007)$ & $.007(.006)$ & $.007(.006)$ & $.006(.006)$ \\
\hline Never worked/retired & $.019(.007)^{*}$ & $.018(.008)^{*}$ & $.016(.007)^{*}$ & $.015(.007)^{*}$ & $.015(.007)^{*}$ \\
\hline \multicolumn{6}{|l|}{ Residential Status } \\
\hline Urban residents & $-.018(.006)^{* * *}$ & $-.023(.006)^{* * *}$ & $-.016(.006)^{* *}$ & $-.019(.006)^{* *}$ & $-.019(.006)^{* *}$ \\
\hline Rural-to-urban migrants & $-.012(.006)$ & $-.011(.007)$ & $-.007(.006)$ & $-.009(.006)$ & $-.009(.006)^{* *}$ \\
\hline Being Religious & $.015(.007)^{*}$ & $.014(.007) *$ & $.011(.007)$ & $.011(.007)$ & $.011(.015)$ \\
\hline General Social Capital & & $.019(.002) * * *$ & --- & $.013(.002)^{* * *}$ & $.013(.002)^{* * *}$ \\
\hline Subjective Social Status & & & $.041(.002)^{* * *}$ & $.040(.002)^{* * *}$ & $.040(.001)^{* * *}$ \\
\hline Wave Dummies & YES & YES & YES & YES & YES \\
\hline Province Dummies & YES & YES & YES & YES & YES \\
\hline Cutoff Point 1 & $-.579(.169)$ & $-.674(.169)$ & $-.462(.159)$ & $-.532(.160)$ & $-.532(.162)$ \\
\hline Cutoff Point 2 & $.233(.171)$ & $.141(.170)$ & $.380(.161)$ & $.312(.162)$ & $.312(.163)$ \\
\hline Cutoff Point 3 & $.927(.171)$ & $.836(.171)$ & $1.099(.161)$ & $1.032(.162)$ & $1.033(.164)$ \\
\hline Cutoff Point 4 & $2.730(.174)$ & $2.645(.174)$ & $2.966(.165)$ & $2.902(.165)$ & $2.902(.167)$ \\
\hline Pseudo R2 & .0595 & .0616 & .0837 & .0848 & --- \\
\hline Wald Chi-square & --- & --- & --- & --- & 26997.26 \\
\hline z-value IV (selection model) & --- & --- & --- & --- & $7.71 * * *$ \\
\hline atanh-rho & --- & --- & --- & --- & $-.006(.028)$ \\
\hline $\mathrm{N}$ & 23,255 & 23,255 & 23,255 & 23,255 & 23,255 \\
\hline
\end{tabular}

Notes: i) average partial effects predicting the highest wellbeing category derived from ordered probits; ii) standard errors in parentheses are robust to heteroscedasticity and adjusted for clustering on prefecture by year; iii) $\mathrm{p}<.005^{*} \mathrm{p}<0.01 * *$ $\mathrm{p}<0.001^{* * *}$ (two-tailed tests); iv) reference groups are: nonreligious, married, very unhealthy, unemployed, rural residents, 2010 wave, and Beijing. 
Table III. The effects of public and private dimensions of religion on wellbeing, 2010 subsample

\begin{tabular}{|c|c|c|c|c|c|}
\hline & Model 1 & Model 2 & Model 3 & Model 4 & Mode 5 \\
\hline \multicolumn{6}{|l|}{ Religious Social Capital } \\
\hline Visiting Religious Sites & $.002(.013)$ & $.001(.014)$ & $-.001(.014)$ & $-.002(.014)$ & $-.001(.013)$ \\
\hline Involvement with religious groups & & $.002(.015)$ & $.001(.015)$ & $-.013(.016)$ & $-.012(.015)$ \\
\hline General Social Capital & & & $.013(.005) *$ & $.013(.005) *$ & $.012(.005)^{*}$ \\
\hline Private Religious Practice (Praying) & & & & $.028(.012) *$ & $.025(.011)^{*}$ \\
\hline Subjective Social Status & & & & & $.044(.004)^{* * * *}$ \\
\hline Wave Dummies & YES & YES & YES & YES & YES \\
\hline Province Dummies & YES & YES & YES & YES & YES \\
\hline All Other Controls & YES & YES & YES & YES & YES \\
\hline Pseudo R2 & .0714 & .0774 & .0783 & .0788 & .105 \\
\hline $\mathrm{N}$ & 3,258 & 3,258 & 3,258 & 3,258 & 3,258 \\
\hline
\end{tabular}

Table IV. Understanding the connection between religion and social status on wellbeing, 2010-2012

\begin{tabular}{lccccc}
\hline \hline & $\begin{array}{c}\text { Model 1 } \\
\text { Oprobit }\end{array}$ & $\begin{array}{c}\text { Model 2 } \\
\text { Oprobit }\end{array}$ & $\begin{array}{c}\text { Model 3 } \\
\text { Oprobit }\end{array}$ & $\begin{array}{c}\text { Model 4 } \\
\text { Oprobit }\end{array}$ & $\begin{array}{c}\text { Model 5 } \\
\text { Oprobit }\end{array}$ \\
\hline Being Religious & $.025(.012)^{*}$ & & $.016(.006)^{*}$ & $.011(.007)$ & $.014(.007)^{*}$ \\
Subjective Social Status & & $.054(.002)^{* * *}$ & $.054(.001)^{* * *}$ & $.040(.002)^{* * *}$ & \\
Wave Dummies & YES & YES & YES & YES & YES \\
Province Dummies & YES & YES & YES & YES & YES \\
All Other Controls & NO & NO & NO & YES & YES \\
Pseudo R2 & .0307 & .0429 & .0431 & .0848 & .0616 \\
$\mathrm{~N}$ & 23,255 & 23,255 & 23,255 & 23,255 & 23,255 \\
\hline
\end{tabular}

Notes: i) average partial effects predicting the highest wellbeing category derived from ordered probits; ii) standard errors in parentheses are robust to heteroscedasticity and adjusted for clustering on prefecture by year; iii) $\mathrm{p}<.005^{*}$ $\mathrm{p}<0.01^{* *} \mathrm{p}<0.001 * * *$ (two-tailed tests); iv) reference groups are: nonreligious, married, very unhealthy, unemployed, rural residents, 2010 wave, and Beijing. 
Table V. The effect of religion on subjective social status, 2010-2012 (OLS)

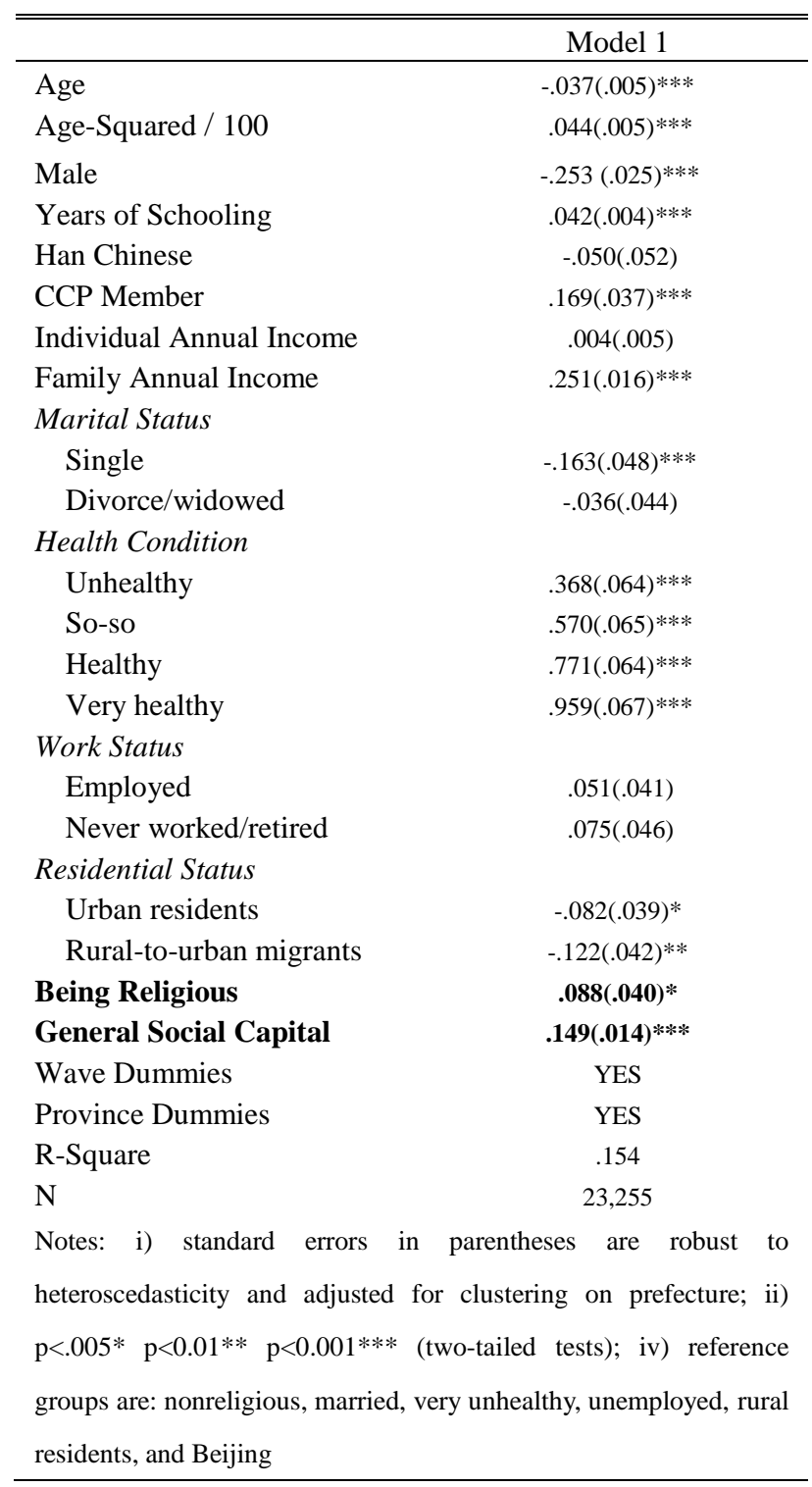

Table VI. Sobel-Goodman test of the mediating effect of subjective social status on religion predicting wellbeing

\begin{tabular}{lccc}
\hline \hline & Coefficient & S.E. & Z \\
\hline Sobel 1 & .0179 & .004 & $4.225^{* * *}$ \\
Goodman 1 (Aroian) & .0179 & .004 & $4.224^{* * *}$ \\
Goodman 2 & .0179 & .004 & $4.227^{* * *}$ \\
\hline Proportion of mediated effect & & & .4026 \\
Ratio of indirect to direct effect & & .6739 \\
Ratio of total to direct effect & & 1.6739 \\
\hline
\end{tabular}


Table VII. The determinants of subjective wellbeing in China, 2010-2012 (disaggregated religious traditions)

\begin{tabular}{|c|c|c|c|c|}
\hline & Model 1 & Model 2 & Model 3 & Model 4 \\
\hline Age & $-.007(.001)^{* * *}$ & $-.007(.001)^{* * *}$ & $-.005(.001)^{* * * *}$ & $-.005(.001)^{* * * *}$ \\
\hline Age Square / 100 & $.010(.001)^{* * *}$ & $.010(.001)^{* * *}$ & $.008(.001)^{* * *}$ & $.008(.001)^{* * *}$ \\
\hline Male & $-.029(.004)^{* * *}$ & $-.031(.004)^{* * *}$ & $-.020(.004)^{* * *}$ & $-.020(.004)^{* * *}$ \\
\hline Years of Schooling & $.003(.0007)^{* * *}$ & $.002(.0007)^{* * *}$ & $.001(.0007)$ & $.001(.0007)$ \\
\hline Han Chinese & $-.028(.007)^{* *}$ & $-.025(.009)^{* *}$ & $-.023(.009)^{* *}$ & $-.022(.008)^{* *}$ \\
\hline CCP Member & $.038(.006)^{* * *}$ & $.038(.006)^{* * *}$ & $.032(.006)^{* * *}$ & $.031(.006)^{* * *}$ \\
\hline Individual Annual Income & $-.00003(.0008)$ & $-.00002(.0008)$ & $-.0004(.0007)$ & $-.0004(.0008)$ \\
\hline Family Annual Income & $.033(.002)^{* * *}$ & $.031(.002)^{* * *}$ & $.022(.002)^{* * *}$ & $.021(.002)^{* * *}$ \\
\hline \multicolumn{5}{|l|}{ Marital Status } \\
\hline Single & $-.083(.008)^{* * *}$ & $-.083(.008)^{* * *}$ & $-.075(.008)^{* * *}$ & $-.076(.007) * * *$ \\
\hline Divorce/widowed & $-.057(.009)^{* * *}$ & $-.057(.009)^{* * *}$ & $-.056(.009)^{* * *}$ & $-.056(.009)^{* * *}$ \\
\hline \multicolumn{5}{|l|}{ Health Condition } \\
\hline Unhealthy & $.071(.014)^{* * *}$ & $.069(.013)^{* * *}$ & $.056(.012)^{* * *}$ & $.055(.012) * * *$ \\
\hline So-so & $.112(.013)^{* * * *}$ & $.109(.012)^{* * *}$ & $.089(.011)^{* * *}$ & $.088(.011)^{* * *}$ \\
\hline Healthy & $.159(.14)^{* * *}$ & $.154(.013)^{* * *}$ & $.126(.012)^{* * *}$ & $.124(.012)^{* * *}$ \\
\hline Very healthy & $.238(.015)^{* * *}$ & $.232(.014)^{* * *}$ & $.197(.013)^{* * *}$ & $.193(.013)^{* * *}$ \\
\hline \multicolumn{5}{|l|}{ Work Status } \\
\hline Employed & $.011(.007)$ & $.009(.007)$ & $.007(.006)$ & $.007(.006)$ \\
\hline Never worked/retired & $.022(.008)^{* *}$ & $.018(.008)^{*}$ & $.016(.007)^{*}$ & $.016(.007)^{*}$ \\
\hline \multicolumn{5}{|l|}{ Residential Status } \\
\hline Urban residents & $-.020(.006)^{* * *}$ & $-.023(.006)^{* * *}$ & $-.016(.006)^{* *}$ & $-.019(.006)^{* *}$ \\
\hline Rural migrants & $-.014(.006)^{*}$ & $-.014(.007)^{*}$ & $-.007(.006)$ & $-.009(.006)$ \\
\hline Buddhism & $.021(.009) *$ & $.020(.009)^{*}$ & $.013(.009)$ & $.012(.010)$ \\
\hline Protestantism & $.028(.013) *$ & $.027(.014)^{*}$ & $.024(.014)$ & $.023(.014)$ \\
\hline Chinese Folk Religion & $.007(.014)$ & $.006(.013)$ & $.007(.014)$ & $.006(.014)$ \\
\hline Islam & $.009(.031)$ & $.009(.033)$ & $.008(.028)$ & $.008(.028)$ \\
\hline Other Religions & $-.020(.022)$ & $-.020(.023)$ & $-.010(.022)$ & $-.010(.022)$ \\
\hline General Social Capital & --- & $.019(.002)^{* * *}$ & --- & $.013(.002) * * *$ \\
\hline $\begin{array}{l}\text { Subjective Social Status } \\
\text { (SSS) }\end{array}$ & & & $.041(.002)^{* * *}$ & $.040(.002)^{* * *}$ \\
\hline Wave Dummies & YES & YES & YES & YES \\
\hline Provincial Dummies & YES & YES & YES & YES \\
\hline Cutoff Point 1 & $-.586(.170)$ & $-.680(.171)$ & $-.464(.161)$ & $-.537(.162)$ \\
\hline Cutoff Point 2 & $.226(.172)$ & $.135(.171)$ & $.377(.162)$ & $.310(.163)$ \\
\hline Cutoff Point 3 & $.920(.172)$ & $.831(.171)$ & $1.097(.162)$ & $1.031(.163)$ \\
\hline Cutoff Point 4 & $2.724(.175)$ & $2.640(.174)$ & $2.963(.166)$ & $2.900(.167)$ \\
\hline Pseudo R2 & .0596 & .0617 & .0838 & .0848 \\
\hline $\mathrm{N}$ & 23,255 & 23,255 & 23,255 & 23,255 \\
\hline
\end{tabular}

Notes: i) average partial effects predicting the highest wellbeing category; ii) standard errors in parentheses are robust to heteroscedasticity and adjusted for clustering on prefecture by year; iii) $\mathrm{p}<.005^{*} \mathrm{p}<0.01^{* *}$ $\mathrm{p}<0.001 * * *$ (two-tailed tests); iv) reference groups are: nonreligious, married, very unhealthy, unemployed, rural residents, 2010 wave, and Beijing. 